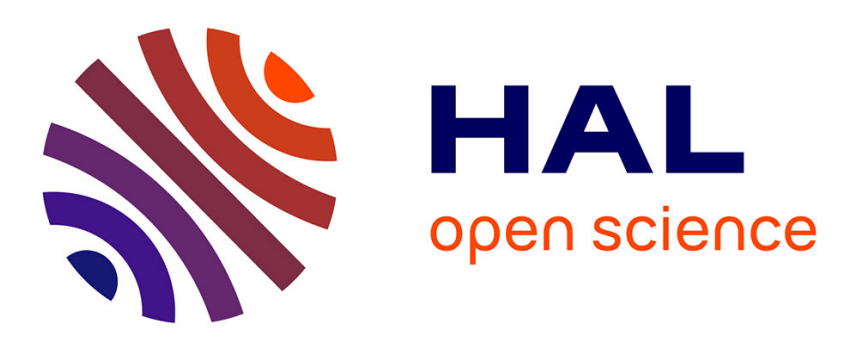

\title{
Parasite survives predation on its host
}

Fleur Ponton, Camille Lebarbenchon, Thierry Lefèvre, David Biron, David

Duneau, David Hughes, Frédéric Thomas

\section{To cite this version:}

Fleur Ponton, Camille Lebarbenchon, Thierry Lefèvre, David Biron, David Duneau, et al.. Parasite survives predation on its host. Nature, 2006, 440 (7085), pp.756-756. 10.1038/440756a . hal02992927

\section{HAL Id: hal-02992927 \\ https://hal.umontpellier.fr/hal-02992927}

Submitted on 6 Nov 2020

HAL is a multi-disciplinary open access archive for the deposit and dissemination of scientific research documents, whether they are published or not. The documents may come from teaching and research institutions in France or abroad, or from public or private research centers.
L'archive ouverte pluridisciplinaire HAL, est destinée au dépôt et à la diffusion de documents scientifiques de niveau recherche, publiés ou non, émanant des établissements d'enseignement et de recherche français ou étrangers, des laboratoires publics ou privés. 
々 Laboratoire GBPH, UMR 6046, Université de Poitiers, 86022 Poitiers, France

e-mail: roberto.macchiarelli@univ-poitiers.fr

1. Bennike, P. \& Fredebo, L. Bull. Hist. Dent. 34, 81-87 (1986).

2. Schwartz, J. H., Brauer, J. \& Gordon-Larsen, P. Am. J. Phys. Anthrop. 97, 77-85 (1995).

3. White, T.D., Degusta, D., Richards, G. D. \& Baker, S. G. Am. J. Phys. Anthrop. 103, 409-414 (1997).

4. Jarrige, C., Jarrige, J.-F., Meadow, R. H. \& Quivron, G. (eds) Mehrgarh Field Reports 1974-1985. From Neolithic Times to Indus Civilization (Department of Culture \& Tourism, Karachi, 1995).

5. Alt, K. W. \& Pichler, S. L. in Dental Anthropology (eds Alt, K. W., Rosing, F. W. \& Teschler-Nicola, M.)
389-415 (Springer, Vienna, 1998).

6. Lukacs, J. R. \& Mindermann, L. L. in South Asian Archaeology 1989 (ed. Jarrige, C.) 167-179 (Prehistory Press Monographic Publication, Madison, 1992).

7. Kenoyer, J. M. \& Vidale, M. in Material Issues in Art and Archaeology III (eds Vandiver, P. B., Druzik, J. R

Wheeler, G. S. \& Freestone, I. C.) 495-518 (Material Research Society, Pittsburgh, 1992).

8. Kenoyer, J. M., Vidale, M. \& Bhan, K. K. World Archaeol. 23, 44-63 (1991).

Supplementary information accompanies this communication on Nature's website. Received 22 November 2005; accepted 1 March 2006. Competing financial interests: declared none. doi:10.1038/440775a

\section{PARASITOLOGY}

\section{Parasite survives predation on its host}

As prisoners in their living habitat, parasites should be vulnerable to destruction by the the parasitic gordian worm Paragordius tricuspidatus is able to escape not only from its insect host after ingestion by a fish or frog but also from the digestive tract of the predator. This remarkable tactic enables the worm to continue its life cycle.

The induced suicide of crickets infected by gordian worms is one of the best known examples of parasite manipulation of host behaviour ${ }^{1}$. Adult gordian worms are free-living in water, where they mate as a knotted mass of multiple individuals. Emergence from the host occurs only after the cricket enters predators of their hosts. But we show here that

the water (for movie, see supplementary information) and may take as long as $10 \mathrm{~min}$ owing to the large size of the worm ${ }^{1}$. During this time, the cricket is active at the surface and attractive to aquatic predators such as fish and frogs (F.T., unpublished observations). Death of the worm would be expected to result from generalist predation upon the host at this stage unless the parasite were capable of an antipredator response.

Few parasites have their own predators, although they are victims of those of their hosts. Predation upon a host may shape parasite life history in two important ways. First, increased predation may select for increased parasite virulence ${ }^{2,3}$ : for example, parasite
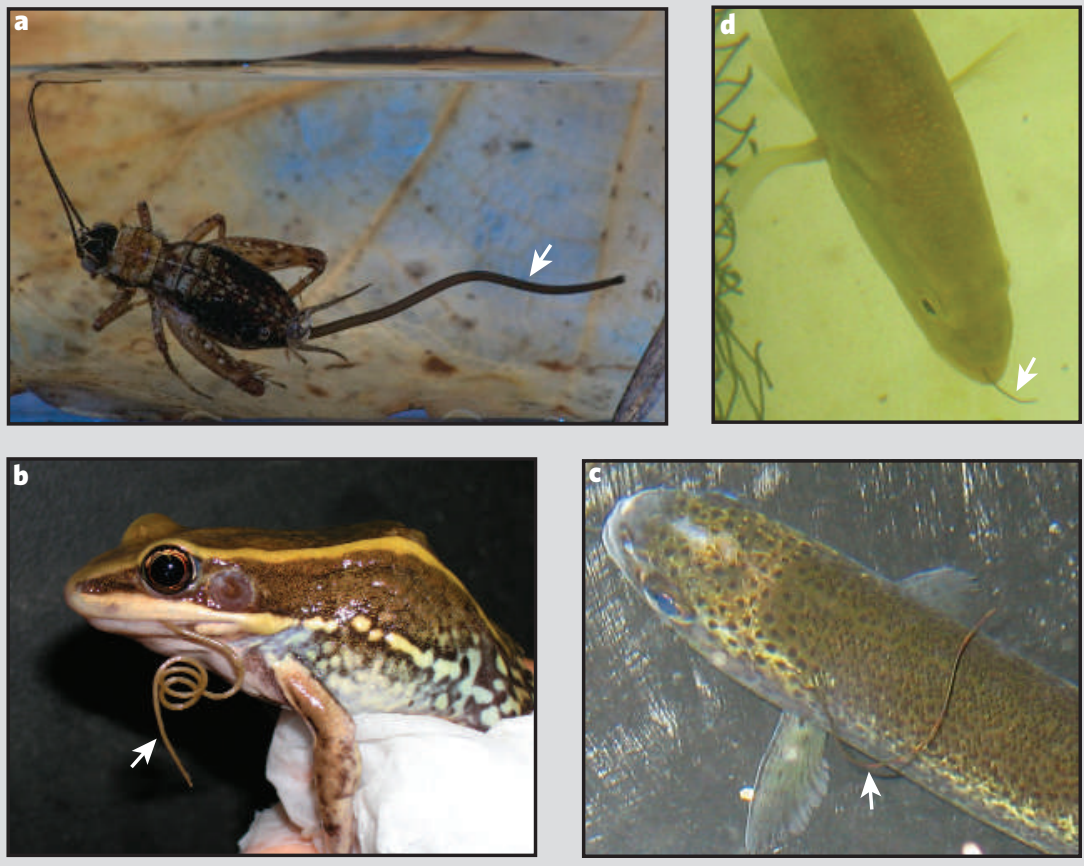

Figure 1 | Escape of parasitic gordian worms from their insect host and from the host's predators. a, Gordian worm (arrow) emerging from a host cricket; b-d, gordian worms (arrows) emerging from a frog (b), a trout (c) and a bass (d) after ingestion of the host insect by these predators. For movies, see supplementary information. development can speed up to minimize the period of host occupancy ${ }^{4}$. Increased virulence may also take the form of manipulating the host's behaviour ${ }^{5}$, for example to remove it from sources of predation ${ }^{6,7}$. Second, predation may affect parasite life history if the predator becomes incorporated into the life cycle ${ }^{8-10}$.

We investigated the response of gordian worms to predation on their host. Under laboratory conditions, we found that crickets that harboured or were expelling gordian worms were often eaten by generalist predators - fish (trout (Oncorhynchus mykiss), perch (Lepomis gibbosus), bass (Micropterus salmoides)) and frogs (Rana erythraea). In none of the 477 predation events that we observed did the predator regurgitate the cricket. Remarkably, the worm escaped predation by wriggling out of the mouth, nose or gills of the predator that had consumed its host (Fig. 1). This escape was recorded from trout $(18 \%, n=141)$, bass $(26 \%, n=292)$, perch $(22 \%, n=27)$ and frogs (35\%, $n=17)$ (for methods, see supplementary information).

The mean time until full emergence was $8.6 \min (518 \pm 208 \mathrm{~s}, n=72)$. The maximum time was $28 \mathrm{~min}$, when the predator repeatedly tried to swallow the worm while it was escaping. If a worm did not start to emerge from the mouth, gills or nose within $5 \mathrm{~min}$, it failed to escape - dying, presumably, in the hostile environment of the predator's stomach. To our knowledge, this escape response by a gordian worm is the first example of a parasite or any organism surviving predation in this way.

Fleur Ponton ${ }^{\star}$, Camille Lebarbenchon ${ }^{\star} \uparrow$,

Thierry Lefèvre ${ }^{\star}$, David G. Biron ${ }^{\star}$,

David Duneau ${ }^{\star}$, David P. Hughes $*$,

Frédéric Thomas ${ }^{\star}$

*GEMI, UMR CNRS/IRD 2724, IRD, BP 64501 ,

34394 Montpellier cedex 5, France

e-mail: fleur.ponton@mpl.ird.fr

†Station Biologique de la Tour du Valat,

Le Sambuc, 13200 Arles, France

†Centre for Social Evolution, Institute of Biology, 21000 Copenhagen, Denmark

. Thomas, F. et al. J. Evol. Biol. 15, 356-361 (2002).

2. Day, T. Proc. R. Soc. Lond. B 269, 1317-1323 (2002).

3. Ebert, D. \& Herre, E. A. Parasitol. Today 12, 96-101 (1996).

4. Harvey, J. A. \& Strand, M. R. Ecology 83, 2439-2451 (2002).

5. Read, A. F. Trends Microbiol. 2, 73-76 (1994)

6. Moore, J. Parasites and the Behavior of Animals (Oxford Univ. Press, Oxford, 2002)

7. Brodeur, J. Norw. J. Agr. Sci. 16, 147-153 (1994).

8. Choisy, M., Brown, S. P., Lafferty, K. D. \& Thomas, F. Am. Nat. 162, 172-181 (2003)

9. Parker, G. A., Chubb, J. C., Ball, M. A. \& Roberts, G. N. Nature 425, 480-484 (2003)

10. Lafferty, K. D. Parasitol. Today 15, 111-115 (1999).

Supplementary information accompanies this communication on Nature's website.

Received 3 January; accepted 10 March 2006. Competing financial interests: declared none. doi: $10.1038 / 440776 a$

BRIEF COMMUNICATIONS ARISING online www.nature.com/bca see Nature contents. 